\title{
Comments
}

\section{THE SELF-INCRIMINATION PRIVILEGE: BARRIER TO CRIMINAL DISCOVERY?}

The California Supreme Court lias for the first time allowed the prosecution to use discovery machinery in a criminal trial. In Jones v. Superior Court, ${ }^{1}$ the district attorney was allowed to discover ${ }^{2}$ the names and addresses of the witnesses and the inedical reports and $\mathrm{X}$-rays the defendant intended to use in support of a defense he planned to raise at trial. The fact that an accused inay now be required to disclose such information makes expedient an examination of the privilege against self incrimination-its history, past applications, and future efficacy in the criminal trial.

The privilege against self incrimination arose late in the development of the common law $;^{3}$ its usage in a criminal proceeding "seems to be founded upon no judicial opinion, but upon a general and silent acquiescence of the courts in a popular demand." In the United States the privilege has been accepted as part of the common $\operatorname{law}^{5}$ and has been raised to the dignity of a constitutional right. ${ }^{6}$ Although the privilege was originally formulated to protect an individual from being his own accuser, ${ }^{7}$ it now serves a dual purpose, protecting both the witness and the accused. The former need not answer any question that might tend to

158 A.C. 55,372 P.2d 919, 22 Cal. Rptr. 879 (1962).

2 It is arguable that the court's order in Jones was not a discovery order but rather a preclusion order. This would mean, in effect, that the court merely told the defendant that if he failed to disclose the names of witnesses who would testify on behalf of his medical history, he would be prevented froin introducing these witnesses at trial. On this basis the case would not infringe upon the self-imcrimination privilege for it would not compel the defendant to hring forth any information. It would appear, however, that even if the order were so termed, the defendant would have hittle choice simce his case hinges upon these witnesses' testimony. Thus, this writer has chosen to interpret the case on the very grounds on which the majority and dissenting opinions are based; namely, that the motion involved is one for discovery. 58 A.C. at $60,64,372$ P.2d at $922,924,22$ Cal. Rptr. at 882,884 .

3 For interesting commentaries on the history of the privilege see 8 WIGMORE, EvIDENCE $\$ 2250$ (McNaughton rev. 1961); Kemp, The Background of the Fifth Amendment in English Law:A Study of its Historical Implications, 1 WM. \& Mary L. Rev. 247 (1958) ; Morgan, The Privilege Against Self-Incrimination, 34 Mnvs. L. Rev. 1 (1949); Riesenfeld, Law-Making and Legislative Precedent in Anterican Legal History, 33 MINN. L. Rev. 103, 116-20 (1949); Note, $44 \mathrm{Kx}$. L.J. 125 (1955).

4 Annot., 118 A.I.R. 602 (1939).

5 Note, $44 \mathrm{Kx}$. L.J. 125, 128 (1955).

${ }^{B}$ The privilege is protected by the fifth amendment of the United States Constitution and by the constitution of every state except Iowa and New Jersey. In Iowa the lack of specific constitutional protection has been overcome by an implication that the privilege is preserved by the mandate against deprivation of life, hberty, or property without due process of law. State v. Height, 117 Iowa 650, 91 N.W. 935 (1902). In New Jersey the privilege is said to exist as part of the common law. State v. Zdanowicz, 69 N.J.L. 619, 55 Atl. 743 (1903).

7 The privilege was originally formulated to prevent the use of "ex officio" oaths in the Star Chamber and the Court of High Commission. These oaths were used to extract confessions of crimes prior to any accusations by the prosecutor. The individuals thus became the instruments of their own condemnation. See 8 WIGMORE, EvIDENCE $\$ 2250$ (McNaughton rev. 1961); Kemp, The Background of the Fifth Amendment in English Law: A Study of its Historical Implications, 1 WM. \& Mary L. Rev. 247 (1958). 
incriminate him, while the latter need not answer any question at all, for he cannot be compelled to bear witness against himself.

The privilege does not furnish an absolute protection for all incriminating evidence the defendant may have. ${ }^{8}$ Rather, it guarantees that the accused cannot be compelled to bring forth such evidence on his own. Wigmore has said that the privilege protects evidence sought to be produced under "testimonial compulsion." This means that the judicial process may not compel the accused to furnish facts that would incriminate him or to produce any chattel or document within his control. ${ }^{10}$

THE BALANCING OF THE PRIVILEGE ${ }^{11}$

The objectives of the administrative and legislative branches of our government have often been balanced against the protection offered by the self-incrimination privilege. For over a century statutes that compel an individual to testify, but grant him immunity from prosecution or deny the use of his testimony against him, have been recognized as a "permissable [encroachment] ... on the Fifth Amendment."12 These statutes balance the state's need for otherwise unobtainable evidence against the protection granted by the self-incrimination privilege. ${ }^{13}$ More recently the privilege has been balanced against the police power of the state in statutes requiring an automobile driver involved in an accident to stop and leave his name and address. ${ }^{14}$ Although such information may lead to an eventual criminal prosecution, these statutes have been deemed necessary for the protection and safety of a state's citizens. ${ }^{15}$

8 The prosecution is allowed to fingerprint the accused, People v. Jones, 112 Cal. App. 68 , 296 Pac. 317 (1931) ; to take specimens of his handwriting, People v. Gormley, 64 Cal. App. 2d 336, 148 P.2d 687 (1944); and to make him pose for identification in the courtroom, Pcople v. Clark, 18 Cal. 2d 449, 116 P.2d 56 (1941). Drunkometer tests using blood extracted from an unconscious person to determine alcoholic intake have also been sanctioned. People v. Haeussler, 41 Cal. 2d 252, 260 P.2d 8 (1953).

O 8 WIGMORE, EVIDENCE $\S 2263$, at 379 (McNaughton rev. 1961).

10 The testimonial utterance implicit in the production of a chattel or document is the defendant's "assurance compelled as an incident of process that the articles produced are the ones demanded." Id. at 380 .

11Although Justice Black denounces the balancing of the privilege as a "recently emphasized constitutional philosophy under which no constitutional right is safe from being 'balanced' out of existence," Cohen v. Hurley, 366 U.S. 117, 133 (1961) (dissenting opinion), the fact remains that such balancing has been a continuous process in the law for over a century.

$12 \mathrm{King}$, Intmunity for Witnesses: An Inventory of Caveats, 40 A.B.A.J. 37 (1954). Two qualifications are normally put on the immunity statutes: (1) The immunity offered must be as broad as the constitutional protection for which it is sought to be suhstituted, and (2) the statutes do not shield the defendant from personal disgrace or odium that often accompanies one's connection with the crime.

13 For a good review of the cases involving immunity statutes and the areas they have covered see Annot., 53 A.L.R.2d 1030, 1034 (1957).

14 See, e.g., CAL. VeHrCle CODE $\$ \$ 20001-16$.

15 See People v. Diller, 24 Cal. App. 799, 142 Pac. 797 (1914); In re Jones, 130 Fla. 667, 178 So. 424 (1938); Ex parte Kneedler, 243 Mo. 632, 147 S.W. 983 (1912). Contra, Reinbrandt v. City of Cleveland, 28 Ohio App. 4, 161 N.E. 364 (1927), holding that such a statute is an infringement of the privilege against self incrimination. 
The Supreme Court has upheld statutes requiring the keeping of certain records that may later be used in a criminal trial. ${ }^{16}$ Although such use may infringe upon the privilege, these public or quasi-public records are sanctioned when there is a "sufficient relation between the activity sought to be regulated and the public concern."17 A similar interest in the protection of the public evidenced itself in the Supreme Court's recent decisions allowing the dismissal of government employees who had refused to answer questions put to them by an investigatory body. ${ }^{18}$ The Court felt that the state's interest in the loyalty of its employees was sufficient reason to uphold statutes requiring an einployee to answer all questions or forfeit his job. ${ }^{19}$

Judicial objectives of the governinent have also been balanced against the selfincrimination privilege. Six jurisdictions now allow comment by the court or prosecutor on the invocation of the privilege. ${ }^{20}$ Such comment is not related to the accused's failure to take the stand, but rather to his failure to explain or deny facts within his knowledge. ${ }^{21}$ Although recognized as a limitation of the privilege, comment is accepted as a justifiable means of arriving at the truth in a criminal trial. ${ }^{22}$

In like manner statutes requiring an advance specification of a defense are in reahty a balancing of the self-incrimination privilege with the desire to provide justice through a thorough investigation of the facts, absent the abuse of lastminute defenses. Several states have statutes requiring that the defense of insanity either be pleaded before trial or be barred. ${ }^{23}$ These statutes have never been challenged as infringing upon the self-incrimination privilege. In addition, alibi statutes

16 Shapiro v. United States, 335 U.S. 1 (1948).

17 Id. at 32. The Court has never adequately defined a public or quasi-public record. Justice Frankfurter has denounced the idea that records are public merely because they are required to be kept by law. Id. at 54 (dissenting opinion). A question of particular interest today involves the status of income tax returns. Several lower courts have held that they are not protected by the privilege. Stillman v. United States, 177 F.2d 607 (9th Cir. 1949); United States v. Willis, 145 F. Supp. 365 (M.D. Ga. 1955). But see Note, 42 B.U.L. REv. 227 (1962), which contends that the privilege may be available to the taxpayer.

18 Nelson v. County of Los Angeles, 362 U.S. 1 (1960) ; Beilan v. Board of Educ., 357 U.S. 399 (1958). The Court in Nelson pointed out that dismissal was not predicated upon the employee's invocation of the fifth amendment, but rather upon the insubordination implicit in his refusal to answer questions. Nelson v. County of Los Angeles, supra at 7.

10 See Nelson v. County of Los Angeles, 362 U.S. 1, 8 (1960). In a similar manner the Court has upheld the disbarment of an attorney who refused to answer questions put to him by a conmittee investigating alleged professional misconduct. Cohen v. Hurley, 366 U.S. 117 (1961).

20 "The six states which allow comment in one form or another do so either by constitutional provision (California and Ohio), by judicial decision (Connecticut, Iowa and New Jersey . . .), or by rules of court procedure (New Mexico)." 8 Wramore, EvinENCE \$ 2272, at 427 n.2 (McNaughton rev. 1961). Contra, State v. Wolfe, 64 S.D. 178, 266 N.W. 116 (1936) (court refused to sustain a statute permitting comment without a constitutional amendinent).

21 People v. Adamson, 27 Cal. 2d 478, 488, 165 P.2d 3, 8 (1946), aff'd sub nom. Adamson v. California, 332 U.S. 46 (1947).

22 Adamson v. California, 332 U.S. 46, 56 (1947). The Court sanctioned conment as a way of "advising the jury in the search for truth." Id. at 56.

23 See, e.g., ARK. Stat. AnN. \$ 43-1301 (1947); CaL. Pen. Code \$ 1016; Colo. Rev. Stat. ANN. § 39-8-1 (1953); Fra. Stat. \& 909.17 (1961); IND. ANn. Stat. § 9-1701 (1956); Iowa CODE \$ 777.18 (1958); MICH. CoMar. LaWs \$\$ 768.20-.21 (1948); UTAH CODE ANN. \$ 77-22-16 (1953); Vt. Stat. Anv. tit. 13, \$\$ 6561-62 (1959); Wash. Rev. Code $\$ 10.76 .020$ (1951); Arzz. RuLes Crom. Proc. 192A (1956). 
have also been enacted in fourteen states to prevent surprise at the trial. ${ }^{24}$ They differ from the insanity statutes in that they require the defendant not only to specify his defense or forfeit it at trial, but also to give varying degrees of information as to his whereabouts at the time of the crime. ${ }^{25}$ Such statutes have, directly or impliedly, been leld constitutional in four states ${ }^{20}$ and accepted without question in the other ten. All of the above examples show that whenever a strong state interest conflicts with the privilege against self incrimination, the privilege must surrender some of its force.

\section{II}

\section{GROWTH OF CRIMINAL DISCOVERY}

The past decade has seen a tremendous growth in criminal discovery, with California the leader in the field. Discovery in a crimmal proceeding was first used in California in $1956 \mathrm{~m}$ the case of People v. Riser. ${ }^{27}$ Since then, its growth "has been little short of phenomenal"28 when one realizes that it has been brought about on a case-by-case basis unaided by the statutory impetus that helped California's civil discovery. In Riser the defendant's attorney felt that statements of the prosecution's witnesses given to police and reported in newspapers conflicted with testimony at the trial. The court allowed the use of a subpoena duces tecum to acquire for impeachment purposes these earlier statements. One year after Riser, the California Supreme Court, in Povell v. Superior Court, ${ }^{29}$ allowed the defendant access, before trial, to his own statement given to the police immediately after his arrest and which he alleged he could not remember. The court stated that to deny this information to the accused

would . . . be to lose sight of the objective of ascertainment of the facts, and would be out of harmony with the policy of this state that the goal of criminal prosecutions is not to secure a conviction in every case by any expedient ineans, however odious, but rather, only through establishing the truth upon a public trial fair to defendant and the state alike..$^{30}$

With these cases as a foundation, Cahifornia courts lave steadily given the defendant greater latitude in the use of discovery machinery. Factors inducing the courts to broaden the accused's discovery privileges have been the elimination of

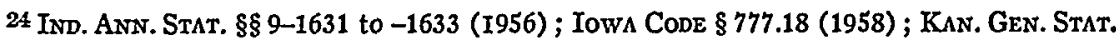
Ann. $\$ 62.1341$ (1949); Mich. Comp. Laws $\$ 8768.20-.21$ (1948); Minn. Stat. $\$ 630.14$ (1947); N.Y. Code Crma. Proc. \$ 295-l; OHIo Rev. Code Ann. $\$ 2945.58$ (1954); OkLA. Stat. tit. 22, $\$ 585$ (1951); S.D. Code \$ 34.2801 (1939); UtaH Code ANN. \$ 77-22-17 (1953); Vt. StaT.

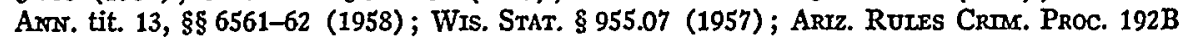
(1956) ; N.J. RULES 3:5-9 (1958).

${ }^{25}$ Some statutes require only that the defendant declare where he was at the time of the crime. Others, however, dictate that the accused not only detail his whereabouts but also the names, post-office addresses, residences, and places of employment of witnesses upon whom he intends to rely. N.Y. CODE CRTM. Proc. 295-l.

26 People v. Wudarski, 253 Mich. 83, 234 N.W. 157 (1931); People v. Rakiec, 260 App. Div. 452, 23 N.Y.S.2d 607 (Sup. Ct. 1940) ; State v. Thayer, 124 Ohio St. 1, 176 N.E. 656 (1931); State v. Kopacka, 261 Wis. 70, 51 N.W.2d 495 (1952).

2747 Cal. 2d 566, 305 P.2d 1 (1956). (1961).

28 Louisell, Criminal Discovery: Dilemma Real or Apparent?, 49 CArT. L. REv. 56, 59

2948 Cal. 2d 704, 312 P.2d 698 (1957).

30 Id. at 707, 312 P.2d at 699-700. 
the precise pleading requirements which had previously given the defendant adequate notice of the exact charges against $\mathrm{him}^{31}$ and the adoption of the liberal federal discovery rules in the civil area. Upon showing something more than a mere desire to obtain all of the information that the People have, ${ }^{32}$ the defendant may presently compel the prosecution to disclose the findings of reports made on certain evidence, ${ }^{33}$ the names and addresses of state witnesses, ${ }^{34}$ the name of an informer who is the only witness to the crime ${ }^{35}$ and the statements the accused has made that have been written down ${ }^{36}$ or recorded. ${ }^{37}$

Discovery rights have centered exclusively on the accused, with the result that the mutuality that is so important in civil discovery has been lacking in Califorma criminal procedure. Several factors have influenced the courts to deny discovery rights to the prosecution. Chief of these has been the fear that to allow any such rights would be a violation of the privilege against self incrimination. ${ }^{38}$ Another important factor has been the feehing that because of the prosecution's superior investigatory powers any discovery privileges are unnecessary.

As more of the prosecution's evidence has become available to the accused without any quid pro quo, district attorneys have begun to put less down on paper in order to thwart discovery..$^{39}$ One author has summed up the situation in this way: "The seedling planted with People v. Riser and Povell v. Superior Court bids fair to become a full grown tree. Doubtless there are district attorneys who would allege that it already has, and that the tree needs pruning."

\section{III}

\section{Jones v. Superior Court}

It was in these circumstances that the recent case of Jones v. Superior Court ${ }^{41}$ was decided by the Cahifornia Supreme Court. In Jones, rather than prune the tree of criminal discovery for the accused, the supreme court planted another seeding -this time for the prosecution. In the process, the self-incrimination privilege was balanced against the need for mutuality in discovery proceedings.

Jones, accused of rape, moved for a continuance on the day of trial on the grounds that he needed more time to gather evidence showing past injuries had rendered him impotent. After the motion was granted, the district attorney moved for discovery of:

(1) the names and addresses of any and all physicians and surgeons subpoenaed to testify on behalf of petitioner with respect to certain injuries ... bearing on the ques-

31 See Goldstein, The State and the Accused: Balance of Advantage in Criminal Procedure, 69 Yate L.J. 1149, 11'2-80 (1960).

32 This limitation was placed on the accused's right to discovery in People v. Cooper, 53 Cal. 2d 755, 770, 349 P.2d 964, 973, 3 Cal. Rptr. 148, 157 (1960).

33 Walker v. Superior Court, 155 Cal. App. 2d 134, 317 P.2d 130 (1957).

34 Norton v. Superior Court, 173 Cal. App. 2d 133, 343 P.2d 139 (1959).

35 People v. Durazo, 52 Cal. 2d 354, 340 P.2d 594 (1959); People v. Williams, 51 Cal.2d

355, 333 P.2d 19 (1958); Mitchell v. Superior Court, 50 Cal. 2d 827, 330 P.2d 48 (1958).

38 Powell v. Superior Court, 48 Cal. 2d 704, 312 P.2d 698 (1957).

37 People v. Cartier, 51 Cal. 2d 590, 335 P.2d 114 (1959).

38 See People v. Riser, 47 Cal. 2d 566, 585, 305 P.2d 1, 13 (1956). (1961).

39 Louisell, Criminal Discovery: Dilemma Real or Apparent? , 49 CALIF. L. REv, 56, 92 n.167

40 Id. at 75.

4158 A.C. 55 , 372 P.2d 919, 22 Cal. Rptr. 879 (1962). 
tion of whether or not petitioner is impotent; (2) the names and addresses of all physicians who have treated petitioner prior to the trial; (3) all reports of doctors or other reports pertaining to the physical condition of petitioner relating to said injuries and hearing on the question of whether petitioner is impotent; and (4) all X-rays of petitioner taken immediately following the 1953 and 1954 injuries.42

The trial court granted this motion and the defendant sought a writ of prohibition. The majority of the supreme court upon appeal (per Traynor, J.) allowed the state the right to search out the defendant's affirmative defense of impotency, but said that the prosecution's motion was too broad. The district attorney was allowed to discover only the names and addresses of those witnesses who would be called at the trial and the medical reports and X-rays that would be introduced into evidence in support of defendant's claim. ${ }^{43}$ Since in past cases the accused's right of discovery had not been granted under any constitutional compulsion, ${ }^{44}$ but under a desire "to promote the orderly ascertainment of the truth,"45 the court felt that the same desire should allow the prosecution-within certain limitsa similar right.

In granting discovery rights to the prosecution, it appears that the Jones court was influenced by two underlying factors. First, the self-incrimination privilege has been subjected to increasing criticism as an anachronism of little value in the criminal trial today; ${ }^{46}$ and second, the true purpose of a criminal trial "is the ascertainment of facts." ${ }^{47}$ This purpose conflicts with the self-incrimination privilege for the privilege's "immediate effect upon the search for truth is to close off one avenue of information about the facts." 48

The majority in Jones, in allowing discovery rights to the prosecution, looked to the alibi statutes of other states. ${ }^{49}$ Reliance on these statutes would seem easily to justify the disovery of the names and addresses of witnesses who would support defendant's claim of impotency. But the supreme court went further, for it also required the production of evidence in the form of medical reports and X-rays that the defendant intended to offer at the trial. ${ }^{50}$ As such, the case appears to be a

42 Id. at 57,372 P.2d at 920,22 Cal. Rptr. at 880.

43 Id. at 60,372 P.2d at 922,22 Cal. Rptr. at 882 . See note 2 supra.

44 Id. at 59, 372 P.2d at 921, 22 Cal. Rptr. at 881.

45 Ibid.

${ }^{48}$ See Goldstein, The State and the Accused: Balance of Advantage in Criminal Procedure, 69 YALE L.J. 1149, 1186 (1960), where the author says:

[T]he protection means less to the defendant than appears: first, the accused will testify in his own behalf in most cases and thus subject himself to cross-examination; second, the prosecutor will rarely wish to inake the accused bis witness; third, the failure of the accused to testify is so conspicuous, particularly in this day of frequent invocation of the fifth amendment, that he is under the utmost pressure to take the stand to rebut the inference of guilt which will likely be drawn by the jury, whether or not his silence is exphicitly called to their attention; finally, admissions made by the accused to the police before trial are freely and regularly used at the trial, placing defendants under pressure to take the stand to explain the admission away.

See also Baker, Self-Incrimination: Is the Privilege an Anachronism?, 42 A.B.A.J. 633 (1956). Contra, Griswold, The FIFTH AMENDMent Today (1955) (a compilation of three speeches given by the Dean of the Harvard Law School defending the privilege).

47 People v. Riser, 47 Cal. 2d 566, 586, 305 P.2d 1, 13 (1956).

48 MCCORMTCK, EvIDENCE $\$ 136$, at 288 (1954).

4958 A.C. at $60-61,372$ P.2d at 922,22 Cal. Rptr. at 882.

$50 \mathrm{~A}$ possible explanation of this allowance stems from the fact that the physician-chent privilege does not exist in a California criminal trial. The court, therefore, may have been expediting the prosecutor's job since he could have obtained this information directly from 
partial repudiation of Wigmore's theory that the self-incrimmation privilege protects all evidence produced through "testimonial compulsion." "51 For no longer are all chattels and documents produced in this manner protected, but only those that the accused does not intend to introduce at the trial.

\section{IV}

\section{PROBLEMS IN Jones}

The Jones decision has not only raised the question of the future scope of criminal discovery, but has also created problems within the narrow confines of its precise holding. The court did not state that a defendant must voluntarily offer details of his affirmative defense. Thus, the problem arises of just how the prosecution is to determine when an affirmative defense is contemplated. In many instances the investigatory powers of the prosecution will lead it to believe that such a defense is to be offered, but there is no indication from Jones that an allegation on information and belief will suffice as the foundation for a successful discovery motion. In Jones there was no problem because the defense was disclosed at the motion for a continuance. Most defendants, lowever, will not display their "hands" as readily.

Jones also presents problems for trial courts who must now distinguish between evidence that supports a defense and that which supports an "affirmative" defense..$^{52}$ The entire Jones court seems to have overlooked the significance of an affirmative defense. In civil trials such a defense implies that the defendant bears the burden of pleading, the burden of proof, and the burden of persuasion. It is doubtful whether the majority meant to go this far in calling the defendant's defense an "affirmative" one. It is therefore unclear exactly what the phrase should be interpreted to mean. A further dilemma is created by the problem of evidence and witnesses not disclosed but offered by the accused at the trial. ${ }^{53}$ Does the defendant run the risk of having new witnesses excluded if he fails to amend his list of witnesses, or is the burden on the prosecution to periodically ask for new names?

\section{$\mathrm{V}$}

FUTURE DEVELOPMENTS

By showing a willingness to allow discovery rights to the prosecution, the California Supreme Court has opened new vistas in the field of criminal discovery. The problems now facing the practitioner are what type, how inuch, and when

the doctor. No mention of such a rationale appears in the case, however, and it would seem a rather dubious manner in which to reach the result. For authority on the denial of the physician-client privilege in the criminal trial see CaL. Code Crv. Proc. \$1881(4), People v. Ditson, 57 Cal. 2d 415, 448, 369 P.2d 714, 733, 20 Cal. Rptr. 165, 184 (1962) ; People v. Lane, 101 Cal. 513, 516, 36 Pac. 16, 17 (1894).

51 See note 9 supra.

62 Peters, J., concurring and dissenting in Jones, states that "any defense other than to attempt to refute the prosecution's witnesses, is an 'affirmative' defense." 58 A.C. at 65,372 P.2d at 925,22 Cal. Rptr. at 885 .

63 This problem would be avoided if the motion were deemed a preclusion order. See note 2 supra. 
criminal discovery is to be allowed. Answers to these questions may be derived under the case method or they may be provided by legislation. The primary attribute of the case method is that it allows gradual development, thus giving the legislature a preview of the rewards and pitfalls of a system prior to any codification. Along these lines, many persons, fearing that perjury and undue influence of witnesses may be concomitant with criminal discovery, feel that the judicial discretion inherent in the case method will minimize these risks. ${ }^{54}$ It is suggested, however, that California judges have rarely limited the defendant's right to discovery and that any reliance on judicial discretion may be unsound. ${ }^{55}$ Since Powell v. Superior Court, ${ }^{56}$ the supreme court has consistently granted the defendant's motion upon his showing something more than a mere desire to know all of the state's information. ${ }^{.7}$

As opposed to a gradual case-by-case development of criminal discovery law, the legislature could immediately define the scope of discovery available to both the prosecution and the defense and establish workable rules to guide judges and lawyers alike. Adequate precedent would seem to exist so as to provide a foundation upon which the draftsmen could build a chapter dealing with the defendant's criminal discovery rights. No body of case law exists, however, from which the legislature could draw in deliniating the prosecution's rights. Thus, the rules laid down in this area would stem wholly from legislative policy determinations balancing the strength of the privilege against self incrimination with the need to obtain evidence, to prevent surprise, and to gain approximate mutuality. Since the granting of discovery riglts to the prosecution necessarily means the protection afforded by the constitutional privilege against self incrimination must be redefined, perhaps the judiciary should withhold its hand from the task of constitutional reconsideration, pending a legislative appraisal. ${ }^{58}$

Should the legislature decide that present statutory action is desirable, possible guidelines to aid the draftsmen are presented in the next few pages.

Civil discovery rules could be used as a model in the criminal area. Of course, criminal discovery cannot be as broad as its civil counterpart because the former must work within the confines of the self-incrimination privilege. This would not, however, preclude the use of the civil rules as a pattern.

54 See Fletcher, Pretrial Discovery in State Criminal Cases, 12 Stan. L. Rev. 293, 322 (1960). In this article reviewing the nationwide growth of discovery for the accused, the author states that the practice should

develop slowly, by a case method, allowing the trial courts to work with discovery of such things in those cases which seem not to involve too great a risk of unreliable testimony, and, incidentally, in that seventy-eight percent of the cases which never come to trial at all, to see whether the good to be done by discovery is outweighed by the harm envisioned by its opponents.

${ }^{65} \mathrm{Mr}$. Fletcher points out that California cases have really been an exception to the case Inethod in that no discretion has been used by the appellate courts. Id. at 322 . However, as noted in the text, a qualification has been placed on the defendant's rights in California. For an opposite view see Louisell, Crinzinal Discovery: Dilemnza Real or Apparent?, 49 CaLrs. L. Rev. 56, 81 n.117 (1961).

5648 Cal. 2d 704, 312 P.2d 698 (1957).

57 See note 32 supra.

58 The dissent in Jones strongly urged that any change in this field should be initiated by the legislature. Justice Peters went so far as to contend that the court in Jones violated the separation of powers doctrine by granting discovery rights to the prosecution. 58 A.C. at 67 , 372 P.2d at 926, 22 Cal. Rptr. at 886. 
Civil discovery is normally thought of as encompassing five basic devices: depositions, interrogatories to adverse parties, motions for inspections, physical and mental examinations, and demands for admissions. ${ }^{59}$ Depositions of witnesses in criminal cases are presently allowed only when the deponent will be unable to attend the trial and his statement is to be used in his stead. ${ }^{60}$ In the one case in which a motion was made to use a deposition for discovery and impeachment purposes ${ }^{61}$ the appellate court-reasoning that such an enlargement of permissible uses of depositions in a criminal trial should stem from the legislature-refused to allow such use. ${ }^{62}$ It is suggested that legislative sanctioning of depositions for discovery and impeachment would be highly advantageous and would allow a more thorough investigation of the facts and decrease the risk of perjured testimony at trial. The accused's self-incrimination privilege would certainly not be a barrier to the adoption of depositions for discovery and impeachment purposes.

The other civil discovery devises all center around the defendant himself. In attempting any transfer of these devices to the criminal area, the legislature must be careful not to infringe upon the privilege's original purpose, thereby causing the defendant to become his own accuser. Physical and inental examinations have long been allowed in Cahifornia criminal trials $s^{63}$ and their codification would not seem to conflict with the privilege. In contradistinction, demands for admissions would clearly violate the privilege and would, thus, be unacceptable.

Any use of depositions and interrogatories to a defendant in a criminal proceeding would appear to be limited - on the basis of Jones-to questions regarding the names and addresses of witnesses and the disclosure of evidence that is to be submitted at trial. ${ }^{64}$ No such limitation need be placed on these devices when used by the defendant, however, for the prosecution is not protected by the self-incrimination privilege. The codification of these devices in the criminal area, therefore, would afford an advantage to the defendant. Arguably, this would be a desirable result. Yet, if the legislature should feel a strong desire to obtam mutuality in the use of discovery machinery, it is suggested that a new discovery device calling for an interchange of witness lists should be adopted. The device would require the prosecution to surrender a list of its witnesses to the defendant, who upon receipt

50 See, e.g., Cax. Code Civ. Proc. \$§ 2016-34.

60 Cax. Pen. Code $\S \S 1335-36,1349$.

61 Clark v. Superior Court, 190 Cal. App.2d 739, 12 Cal. Rptr. 191 (1961). There have only been three other cases in the United States. in which a deposition has been sought for similar purposes, and such usage was denied in all three cases. Ex parte Denton, 266 Ala. 279, 96 So. 2 d 296 (1957) ; Reed v. Allen, 121 Vt. 202, 153 A.2d 74 (1959); State v. Christensen, 40 Wash. 2d 329, 242 P.2d 755 (1952).

62 Clark v. Superior Court, 190 Cal. App. 2d 739, 743, 12 Cal. Rptr. 191, 193 (1961). The court pointed out that the hiberalization in California of the use of depositions apphed only to civil trials. It also suggested that implicit in the legislature's failure to amend the criminal rules was a desire to retain the status quo. The court also relied on the fact that Cax. Const. art. I, § 13, provides for particular instances in which depositions may be taken. However, whether this section is exclusive or not has never been ruled upon by the California Supreme Court and the opposite conclusion is quite possible.

03 See People v. One 1941 Mercury Sedan, 74 Cal. App. 2d 199, 168 P.2d 443 (1946), for an excellent summary of the law regarding physical examinations and the conclusion that the results of such examinations are not excludable from the trial. For mental examinations see Car. Pen. Code $\$ 1027$.

64 In a sense the Jones court was sanctioning the use of interrogatories by allowing the prosecution to discover the evidence to be offered and the witnesses to be called. 
would have a specified number of days to reciprocate with a similar list. ${ }^{65}$ If good cause be shown, an amendment of either list-even at trial-should be allowed, with the sanction that any nonlisted witness be excluded from testifying. ${ }^{60}$ These lists coupled with the investigatory powers of the participants should allow each side sufficiently to frame the issues in order to prevent surprise at the trial. Further, the use of such a procedure would prevent a sharp contrast between the use of depositions in criminal and civil trials.

Motions for inspections could feasibly be used in the criminal area. ${ }^{67}$ The moving party, as in civil trials, would be required to specify the exact type of evidence desired to be inspected. The basis of the prosecution's use of such motion would have to be limited, not to admissibility, but rather to the defendant's intention to introduce the sought after evidence at trial. ${ }^{68}$ Since the state is not shielded by the self-incrimination privilege, no such limitation need be placed on the accused's motion. In essence, such a statute would codify the present law as illustrated by Jones and the cases since Riser.

As an alternative to a piecemeal adaptation of civil discovery devices to the criminal field, a more comprehensive solution is available to the California Legislature. As noted earlier, ${ }^{69}$ the self-incrimination privilege as interpreted today protects the defendant both as an accused and as a witness. Working with this premise of dual protection, a statute could be drafted denying the use of discovery to either the prosecution or the defendant unless the latter waived his special status as an accused..$^{70}$ While such a waiver would render the defendant amenable to inquiry, his status as a witness would provide protection from those questions

65 WASEr. REv. CODEs $\S 10.37 .030$ (1951), requires the prosecutor to furnish the accused a list of his witnesses, and within five days the defendant must reciprocate. In practice, however, "the Washington statute is rarely observed by the defendant, since the statute does not provide the complementary sanction of possible exclusion of the nonlisted witness' testimony." Fletcher, Pretrial Discovery in State Criminal Cases, 12 Stan. L. Rev. 293, 315-16 (1960).

Although the author realizes that such a statute would not be limited to "affirmative" defenses, and as such would go beyond the Jones holding, it is contended that the statute would be within California's constitution. The Supreme Court has stated that a state has "great leeway in defining the reach of its own privilege against self-incrimination." Cohen v. Hurley, 366 U.S. 117, 125 (1961).

G6 See note 65 sucpra.

07 The Cahifornia Supreme Court in substance, if not in form, allowed the use of this device in Jones when it allowed the prosecution to inspect the medical records and $\mathrm{X}$-rays of the defendant.

68 This limitation appears to be placed on the prosecution in Jones. It seems to be a pragnatic limitation affording a definitive stopping piace. The argument may be made that any evidence the defendant intends to offer on his behalf must be for the purpose of exoneration, not incrimination.

69 See text following note 7 supre.

${ }^{70} \mathrm{~A}$ statute based along these same lines was proposed in Goldstein, The State and the Accused: Balance of Advantage in Criminal Proceducre, 69 Yaxe L.J. 1149, 1198 (1960). A type of mutuality statute apphicable only to criminal syndicates was also proposed recently in Louisell, Criminal Discovery: Dilemma Real or Apparent?, 49 CaLrr. L. Rev. 56, 101 (1961).

In McCain v. Superior Court, 184 Cal. App. 2d 813, 7 Cal. Rptr. 841 (1960), the court applied a similar rule. The defendant filed a motion for the discovery of certain data in the hands of the state. The prosecution filed a similar motion and requested that its granting be a condition precedent to the allowance of the accused's motion. Defendant's lawyer did not object and the trial court granted both motions. The petitioner handed over the sought-after documents and subsequently put on record that he objected on the grounds that such procedure violated his privilege as a defendant. The appellate court refused to honor this defense on the grounds that he had waived the privilege by not making a timely objection. 
which are incriminating. Concomitant with this procedure, the civil rules of discovery could be adopted in their entirety, subject to the restriction that they be available only upon the defendant's voluntary waiver. A statutory scheme drafted along these lines would give the accused his choice of remaining mute or of using discovery machinery on the condition that such be available to the state as well. Viewed in its historical perspective, the self-incrimination privilege was not intended to allow the defendant to be completely silent; rather, its purpose was to protect him from being his own accuser. ${ }^{71}$ The above statute would preserve this original purpose of the privilege, while at the same time allowing both sides to test each other's evidence and legal contentions in the best traditions of the adversary system.

\section{CONCLUSION}

The California Supreme Court's willingness to balance the self-incrimination privilege with the need for equality in discovery proceedings illustrates that within certain limits the privilege and criminal discovery are not mutually exclusive. The Jones decision has opened an area of the law which heretofore was thought to be effectively foreclosed by the privilege against self incrimination. Now that discovery rights are to be available to the prosecution, some method of structuring these new rights must be undertaken. It is suggested that the case method which has previously been used to delineate discovery rights should be replaced by legislation. Criminal discovery procedures should be codified so as to provide workable rules defining the present scope of permissible discovery. Two possible legislative solutions have been presented. Of the two, the solution embodying the use of a waiver statute seems to be the more desirable. Such a statutory scheme would afford the defendant the full protection of the privilege against self incrimination while at the same time allowing the utmost use of discovery machmery once that machinery were put into motion. It would also tend to reduce the necessity of drawing borderline distinctions between what is and what is not discoverable $\mathrm{m}$ the criminal trial and would simphify the use of criminal discovery by the practitioner since the devices to be used would be those now familiar in the civil area.

Kendall R. Bishop 